\title{
Vulnerability and Weaknesses of Eating Habits of Overweight School Children as an Entry Risk for COVID-19
}

Ammal M. Metwally ${ }^{1 *}$, FatmaA. Shaaban ${ }^{2}$, Walaa S. Mahmoud ${ }^{3}$, Ebtissam M. Salah ${ }^{2}$, Marwa M. El-Sonbaty $^{2,4}$, Hanan A. Hussien $^{5}$, Nabih Abdel Hamid ${ }^{5}$, Lobna A. El Etreby ${ }^{1}$, Amal Hassanin ${ }^{5}$, Zeinab M. Monir ${ }^{2}$

${ }^{1}$ Community Medicine Department, Medical Research Division, National Research Centre (ID: 60014618), P.O. 12622, Dokki, Cairo, Egypt; ${ }^{2}$ Child Health Department, Medical Research Division, National Research Centre (ID: 60014618), P.O. 12622, Dokki, Cairo, Egypt; ${ }^{3}$ Biological Anthropology Department, Medical Research Division, National Research Centre (ID: 60014618), P.O. 12622, Dokki, Cairo, Egypt; ${ }^{4}$ Department of Pediatrics, College of Medicine, Taibah University, Madinah, KSA; ${ }^{5}$ Agricultural Research Centre, Giza, Egypt

Edited by: Mirko Spiroski Citation: Metwally AM, Shaaban FA, Mahmoud WS, Salah EM, El-Sonbaty MM, Hussien HA, Hamid NA El Etreby LA, Hassanin A, Monir ZM. Vulnerability and Weaknesses of Eating Habits of Overweight Schoo Man an https:/loi. 2020 Aug $30,8(T 1) .158-166$. htps./doi. 2020 Aug 30; $8(T 1): 158-106$. Primary school children: Nutrient-rich food; Calorie dense food; Dietary behavio 'Correspondence: Prof. Dr. Ammal M. Metwally, Prof blic Health and Community Medicine, Medical Research Division, National Research Centre, Giza 12411, Egyp Tel: +20 122228 0640. Fax: (+202)33370931. E-mail: am.metwally@nrc.sci.eg Received: 04-Jun-2020 Accepted: 20-Jul-2020 opyright: ๑ 2020 Ammal M. Metwally, Fatma A. Shaaban, Walaa S. Mahmoud, Ebtissam M. Salah, Marwa M. El-Sonbaty, Hanan A. Hussien, Nabih Abdel Hamid, Lobna A. El Etreby, Amal Hassanin, Zeinab M. Monir Funding: Publication of this article was financially supported by the Scientific Foundation SPIROSKI, Skopje, Republic of Macedon Competing Interests: The authors have declared that no competing interest exists Open Access: This is an open-access antle distributed onCommercial 4.0 International License (CC BY-NC 4.0)

\section{Abstract}

BACKGROUND: In developing countries, overweight among children becomes an alarming problem and a health concern. Obesity is a factor in disease severity of coronavirus disease (COVID-19) having the greatest impact on patients.

AIM: The aim of this study was to determine the prevalence of overweight in some of the Egyptian governmenta primary school children, its nutritional and socioeconomic determinants. Special focus was directed to identify the current dietary practices including risky nutritional habits of overweight children as a weak point leading to increasing their vulnerability to catching COVID-19 infection.

METHODS: A cross-sectional observational study was conducted on primary school children aged 6-12 years General demographic data, socioeconomic data, dietary pattern, intake of a diversity of nutrient-rich food versus calorie-dense food, and anthropometrical data were collected.

RESULTS: Of 1600 child, there were $8 \%$ overweight who are considered at risk of COVID-19 infection. Considering the weekly share of the stomach, only one-third of the food consumed by overweight children is nutrient-rich, with high consumption of French fries and Candies (once per day among $95 \%$ and $78 \%$ of overweight children, respectively). Moreover, $90 \%$ of them consume sugar-sweetened beverages (SSB) more than once per day. The majority of overweight children belonged to small, middle- income families, and had illiterate or read and write mothers.

CONCLUSION: Overweight children eat narrow diversity of nutrient-rich food that includes vegetables, fruits, protein and dairy products. They eat more calorie-dense foods, every day. The increase of family income increased the likelihood of having overweight children with a high intake of SSB, candies, and chips; consumption of snacks between meals and before sleep. Protective predictors against overweight were highly educated mothers, taking breakfast before school, having dinner, and taking meals on time.

RECOMMENDATION: Nutritional behavioral education aiming at choosing nutritious and varied options of food that is effective for improving children's nutritional status is the key to decreasing vulnerability toward COVID 19.

\section{Introduction}

The WHO considers non-communicable diseases such as obesity, a major risk factor for becoming seriously ill with 2019 novel coronavirus disease (COVID-19).

The ongoing coronavirus pandemic 2019 (COVID-19) has millions of confirmed cases all over the world with claimed millions of lives [1]. The WHO considers obesity out of the major risk factors for catching the novel 2019 coronavirus (COVID-19). Good nutrition is considered an essential aspect for defense against COVID-19. Accordingly, one of the key elements for a society's readiness to combat this threat could be achieved through nutritional resilience. Fortunately, focusing on nutritional well-being is among the 2030 Agenda for Sustainable Development, through which the opportunities for establishing synergies between public health and equity could be achieved [2], [3].

A positive energy balance diet leads to overweight and obesity; its prevalence can be estimated using anthropometrics [4]. Overweight is due to excessive fat accumulation; overweight is defined as a body mass index (BMI) at or above the $85^{\text {th }}$ percentile and below the $95^{\text {th }}$ percentile for children and teens of the same age and sex [5].

School-aged children are an important part of the community. The school environment can be an enabling factor for the correction of many nutritional problems [6]. Concerning the fact that nutritional behaviors among children are not so strongly formed and it is easier to modify and develop them in children than in adults, the eating habits acquired or changed during childhood will be likely to track into adulthood [7]. 
It is important to seize this window of opportunity to get on track toward the sustainable development goals target of ending malnutrition in all its forms by 2030 [8].

There is an alarming increase in overweight in children and adolescents [9]. The consequences of overweight in childhood, including persistence into adulthood and as a risk factor for adverse health consequences (heart disease morbidity and mortality, ovulatory dysfunction, metabolic syndrome, arthritis, gout, and mental health diseases), are of substantial concern given the recent upward trend in prevalence [10], [11]. With the fact that overweight will lead to increased risks of obesity and in this critical period of life, adolescence has major importance not only for their affection but also for their societies. Where obese adolescents, especially with visceral obesity usually will track into obesity in their adulthood, subsequently leads to various medical health complications [12].

The aim of this study was to determine the prevalence of overweight in some of the Egyptian governmental primary school children, its nutritional and socioeconomic determinants. Special focus was directed to identify the weaknesses of the eating habits of overweight children as a weak point leading to malnutrition and increasing their vulnerability to catching COVID-19 infection.

\section{Methodology}

\section{Study design}

The study was a cross-sectional one that was conducted in three governorates; one representing lower Egypt (Behara governorate), one representing the coastal region (Damietta governorate), and one representing upper Egypt (Fayoum governorate) to represent the different geographical regions in Egypt with different nutritional habits.

\section{Sampling frame and sampling unit}

Three sampling frames were chosen: The first sampling frame used was based on stratification of the served rural governorates into three strata representing rural lower Egypt, coastal region, and upper Egypt governorates. The second sampling frame was based on a comprehensive list of the governorates as per regions. The third sampling frame was the stratification of listing the units to be sampled (governmental primary school children). For the third sampling frame, a logical order was used for schools and then a cluster of schools was chosen with probability proportion to size from that listing. This ensured that the units were evenly distributed within the listing and avoided the possibility that, due to chance, one type of school ends up being under-represented.

\section{Sample size}

A sample size of 1574 to be rounded to 1600 produces a two-sided $95 \%$ confidence interval with a width equal to 0.050 when the sample proportion is 0.500 [13], [14].

Confidence intervals for one proportion - new numeric results for two-sided confidence intervals for one proportion confidence interval formula: Exact (Clopper-Pearson).

\begin{tabular}{llllllll}
\hline Sample & & & & & & & \\
\hline Confidence & Size & Target & Actual & Proportion & Lower & Upper & Width if \\
\hline Level & $(\mathrm{N})$ & Width & Width & $(\mathrm{P})$ & Limit & Limit & $\mathrm{p}=0.5$ \\
0.950 & 1574 & 0.050 & 0.050 & 0.500 & 0.475 & 0.525 & 0.050 \\
\hline
\end{tabular}

\section{Study participants}

The choice of subjects was in the form of clusters (6 clusters/each school); each cluster was formed from 10 students from each grade with a total of 60 children/each primary school children. The actual total number of the randomly surveyed schools was 29 schools distributed along 16 districts within the three governorates with average 1-3 schools/district and 8-10 schools/each of the selected governorates according to the number of schools per district.

\section{Inclusion criteria}

Apparently healthy prepubescent boys and girls in the primary schools with six grades were included in the study. The primary school children are aged 6-12 years.

\section{Exclusion criteria}

Students proved to have any mental disorder or chronic diseases were excluded from the study.

\section{Methods}

Three well-structured questionnaires were administered to each student; questionnaires were designed for assessment of nutritional status, dietary pattern, and socioeconomic factors. A pilot study was done on $10 \%$ of the children for testing the questionnaires.

\section{Nutritional status assessment}

Nutritional status assessment was carried out through Anthropometric measurements of (weight and height). All measurements were made according to techniques described in the anthropometric standardization reference manual [15]. Anthropometric measurements were taken, height was measured to the nearest $0.1 \mathrm{~cm}$ using a Holtain portable anthropometer, and weight was determined to the nearest $0.01 \mathrm{~kg}$ using a seca scale balance with the subject dressed in minimal clothes and 
without shoes. The BMI was calculated as weight (in kilograms) divided by height (in meters) squared, and after the morning exercises of spine stretching. All scores were calculated based on the WHO growth standards with the help of the Anthro-Program of PC [16].

Overweight is defined as a BMI at or above the $85^{\text {th }}$ percentile and below the $95^{\text {th }}$ percentile for children and teens of the same age and sex. Anthropometric indicators provide useful summary measures of nutritional status based on measures of body size and composition, often relative to their distribution in a reference population. Anthropometric indicators measure achieved nutritional status, rather than nutrition inputs, are less subject to measurement error, and are less expensive to collect than dietary intake data.

\section{Dietary pattern assessment}

Students provided data on their diet to evaluate dietary habits and behavior of children (skipping breakfast, number of daily meals, eating the served school meal, and source of other meals consumed during the school day). Special emphasis was focused on comparing the intake of different diversity of nutrient-rich foods (this includes: vegetables, fruits, and nutrient-rich sources of protein and dairy) versus calorie dense foods with low levels of nutrients, every day, and every week. Moreover, the intake of SSB per day was also assessed.

The following indicators that are related to the daily share of the plate were measured:

- $\quad$ Number of meals served in proportions as per
- $\quad$ Frequency of meals served in proportions as
per plate
- $\quad$ Number of nutrient-rich foods eaten per day.

The following indicators that are related to the weekly share of the stomach were measured:

- $\quad$ Diversity of nutrient-rich foods eaten per week

- Number of types of nutrient-rich foods eaten per week

- $\quad$ Frequency of nutrient-rich foods overall and per food groups eaten per week.

\section{Statistical analysis}

Data were analyzed using Statistical Package for the Social Sciences (SPSS) version 21.0 software. All data were represented by percentages and comparisons between groups were done using odds ratio, to study the association of the studied parameters with overweight and Chi-square to study the pattern of distribution of the studied parameters between normal children and overweight ones. Probability values (p) $<0.05$ were regarded as statistically significant. Logistic regression analysis and was done to assess the contribution of each independent variable in explaining the predictors of overweight [17].

\section{Results}

Children who did not have breakfast before going school carried more than 4 times the risk to be overweight $(\mathrm{OR}=4.031)$. Children who did not take meals on time carried more than 3 times risk to be overweight $(\mathrm{OR}=3.31)$, while children who did not take breakfast and break snacks, who did not have dinner, and who took snacks before sleep carried more than double risk to be overweight $(\mathrm{OR}=2.82, \mathrm{OR}=2.53$, $\mathrm{OR}=2.2$ ), respectively. Snacks between-meal carried almost 2 times the risk of being obese $(\mathrm{OR}=1.89)$ (Table 1).

Table 1: Comparing dietary behavior in overweight and normal weight children

\begin{tabular}{|c|c|c|c|c|}
\hline Parameters & $\begin{array}{l}\text { Overweight } \\
(n=128) n(\%)\end{array}$ & $\begin{array}{l}\text { Normal } \\
(n=1472) n(\%)\end{array}$ & $\begin{array}{l}\text { Test of sig. odds } \\
\text { ratio }(\mathrm{Cl})\end{array}$ & $\begin{array}{l}p \text { value of } \\
\text { Chi-square }\end{array}$ \\
\hline \multicolumn{5}{|c|}{ Breakfast and break snacks } \\
\hline No $(n=838)$ & $95(74.2)$ & $743(50.5)$ & \multirow[t]{2}{*}{$2.82^{*}(1.88-4.25)$} & \multirow[t]{2}{*}{$<0.001^{*}$} \\
\hline Yes $(n=762)$ & $33(25.8)$ & $729(49.5)$ & & \\
\hline \multicolumn{5}{|c|}{ Breakfast before school } \\
\hline No $(n=141)$ & $25(32.9)$ & $116(10.8)$ & \multirow[t]{2}{*}{$4.031^{*}(2.41-6.75)$} & \multirow[t]{2}{*}{$<0.001^{*}$} \\
\hline Yes $(n=1005)$ & $51(67.1)$ & $954(89.2)$ & & \\
\hline \multicolumn{5}{|c|}{ Source of breakfast and or snacks } \\
\hline Other $(n=1121)$ & $75(98.7)$ & $1046(97.8)$ & \multirow[t]{2}{*}{$1.72(0.23-12.89)$} & \multirow[t]{2}{*}{$>0.05$} \\
\hline Home $(n=25)$ & $1(1.3)$ & $24(2.2)$ & & \\
\hline \multicolumn{5}{|l|}{ Number of meals } \\
\hline$<3(n=191)$ & $18(14.1)$ & $173(11.8)$ & \multirow[t]{2}{*}{$1.23(0.73-2.07)$} & \multirow[t]{2}{*}{$>0.05$} \\
\hline$\geq 3(n=1409)$ & $110(85.9)$ & $1299(88.2)$ & & \\
\hline \multicolumn{5}{|l|}{ Meals on time } \\
\hline No $(n=662)$ & $87(68)$ & $575(39.1)$ & \multirow[t]{2}{*}{$3.31^{*}(2.25-4.87)$} & \multirow[t]{2}{*}{$<0.001^{*}$} \\
\hline Yes $(n=938)$ & $41(32)$ & $897(60.9)$ & & \\
\hline \multicolumn{5}{|c|}{ Snacks/anything between meals } \\
\hline Yes $(n=1233)$ & $110(85.9)$ & $1123(76.3)$ & \multirow[t]{2}{*}{$1.89^{*}(1.14-3.17)$} & \multirow[t]{2}{*}{$<0.001^{*}$} \\
\hline No $(n=367)$ & $18(14.1)$ & 349 (23.7) & & \\
\hline \multicolumn{5}{|l|}{ Mid-day snack } \\
\hline Yes $(n=1433)$ & $115(89.8)$ & $1318(89.5)$ & \multirow{2}{*}{$1.03(0.57-1.87)$} & \multirow[t]{2}{*}{$>0.05$} \\
\hline No $(n=167)$ & $13(10.2)$ & $154(10.5)$ & & \\
\hline \multicolumn{5}{|c|}{ (Snacks before sleep sweets, chips...etc.) } \\
\hline Yes $(n=676)$ & $77(60.2)$ & $599(40.7)$ & \multirow[t]{2}{*}{$2.2^{*}(1.52-3.18)$} & \multirow[t]{2}{*}{$<0.001^{*}$} \\
\hline No $(n=924)$ & $51(39.8)$ & $873(59.3)$ & & \\
\hline \multicolumn{5}{|l|}{ Dinner } \\
\hline No $(n=248)$ & $38(29.7)$ & $210(14.3)$ & \multirow[t]{2}{*}{$2.53^{*}(1.69-3.81)$} & \multirow[t]{2}{*}{$<0.001^{*}$} \\
\hline Yes $(n=1351)$ & $90(70.3)$ & $1262(85.7)$ & & \\
\hline
\end{tabular}

Considering the weekly share of the stomach, almost half $(48 \%)$ of the food consumed by normal children was nutrient rich, due to the consumption of dairy and beans/meat versus one-third (31\%) among overweight children. French fries were consumed less than once per day among $95 \%$ of overweight children while candies nearly once per day among $78 \%$ of them. On the other hand, chips and SSB were consumed more than once per day among (96\% and $90 \%$, respectively) of overweight children (Table 2).

Share of the plate as per meals carried more than the double risk to be overweight when the percentage of energy-dense food is more than nutrientrich food in breakfast and lunch $(\mathrm{OR}=2.38$, OR $=2.34$ ), respectively, while in case of dinner and snack between meals it carried almost 2 times risk (OR = 1.89 for each) (Table 2).

Child order did not have an effect on physical growth. The majority of overweight children belonged to small families $(68.0 \%)$, middle-income families $(60.9 \%)$, and had illiterate or read and write mothers $(61.7 \%)$. Consequently, large family size, low-income family, and highly educated mothers had reduced risk 
of having overweight children $(\mathrm{OR}=0.46,0.55$, and 1.9 , respectively) (Table 3 ).

It was found those positive predictors, increasing the risk of overweight, increased family income; intake of SSB, candies, and chips; consumption of snacks in between meal and before sleep. On the other hand, negative predictors, protecting against overweight, were taking breakfast, taking breakfast before school, having dinner, taking meals on time, an increase of family size, and an increase of maternal education (Table 4).

\section{Discussion}

The nutritional status is a well-known risk factor for the development of metabolic and endocrine disorders and recently it was suggested that it can also affect the immune function with a subsequent increase risk for infection [18]. In industrialized countries, the infection rate was found to be increased in obese and adolescent children leading to the subsequent association of childhood obesity with a low-grade

Table 2: Comparison of the weekly and daily dietary intake of nutrient-rich foods versus energy dense food between the overweight and normal weight children

\begin{tabular}{|c|c|c|c|c|}
\hline Parameters & Overweight $(n=128) n(\%)$ & Normal $(n=1472) n(\%)$ & Test of sig. odds ratio $(\mathrm{Cl})$ & $\mathrm{p}$ value of Chi-square \\
\hline \multicolumn{5}{|c|}{ Diversity of nutrient-rich foods (vegetables, fruits, nutrient-rich sources of protein, and dairy products) eaten per week } \\
\hline Nutrient-rich foods (overall) & $40(31 \%)$ & $707(48 \%)$ & $2.03(1.38-2.99)^{*}$ & \multirow[t]{3}{*}{$<0.001^{*}$} \\
\hline Energy dense food & $40(31 \%)$ & $339(23 \%)$ & $1.52(1.03-2.25)^{*}$ & \\
\hline Carbohydrates/grains & $48(38 \%)$ & $426(29 \%)$ & $1.47(1.01-2.14)^{*}$ & \\
\hline \multicolumn{5}{|c|}{ Share of the stomach (frequency of nutrient-rich foods as per food groups eaten per week) } \\
\hline Dairy & $13(10 \%)$ & $250(17 \%)$ & $1.81(1.00-3.26)^{*}$ & \multirow[t]{4}{*}{$>0.05$} \\
\hline Meat/beans/eggs & $12(9 \%)$ & $236(16 \%)$ & $1.85(1.00-3.39)^{*}$ & \\
\hline Fruits & $10(8 \%)$ & $147(10 \%)$ & $1.30(0.67-2.55)$ & \\
\hline Vegetables & $5(4 \%)$ & $74(5 \%)$ & $1.30(0.52-3.28)$ & \\
\hline \multirow{2}{*}{\multicolumn{5}{|c|}{ Proportion and types of the most weekly consumed unhealthy food among children }} \\
\hline Weekly consumption & & & & \\
\hline French fries & $122(95 \%)$ & $1222(83 \%)$ & $4.16(1.8-9.5)^{\star}$ & \multirow[t]{8}{*}{$>0.05$} \\
\hline Chips & $123(96 \%)$ & $1266(86 \%)$ & $4.00(1.6-9.9)^{*}$ & \\
\hline Sugar sweetened beverages & $115(90 \%)$ & $986(67 \%)$ & $4.36(2.4-7.8)^{*}$ & \\
\hline Candies & $100(78 \%)$ & $692(47 \%)$ & $4.02(2.6-6.2)^{*}$ & \\
\hline Biscuits & $99(77 \%)$ & $1001(68 \%)$ & $1.61(1.0-2.5)^{\star}$ & \\
\hline Chocolate & $93(73 \%)$ & $1001(68 \%)$ & $1.25(0.83-1.87)$ & \\
\hline Pancakes/cakes & $78(61 \%)$ & $898(61 \%)$ & $0.99(0.69-1.45)$ & \\
\hline Ice cream & $76(59 \%)$ & $765(52 \%)$ & $1.35(0.93-1.95)$ & \\
\hline \multicolumn{5}{|l|}{ Frequency intake per week } \\
\hline French fries & 5.6 & 4.4 & & \\
\hline Chips & 8.2 & 6.1 & & \\
\hline Beverages (SSB) & 9.5 & 4.6 & & \\
\hline Candies & 6.8 & 4.1 & & \\
\hline Biscuits & 4.3 & 3.9 & & \\
\hline Chocolate & 3.5 & 3 & & \\
\hline Pastries/pancakes/cakes & 4.2 & 3.9 & & \\
\hline Ice cream & 3.8 & 3.4 & & \\
\hline \multicolumn{5}{|l|}{ Share of the plate as per meals } \\
\hline \multicolumn{5}{|l|}{ Breakfast } \\
\hline Energy dense food & $29(23 \%)$ & $162(11 \%)$ & $2.38(1.49-3.82)^{\star}$ & $<0.001^{*}$ \\
\hline Nutrient-rich foods (overall) & $63(49 \%)$ & $839(57 \%)$ & & \\
\hline \multicolumn{5}{|l|}{ Lunch } \\
\hline Energy dense food & $13(10 \%)$ & $74(5 \%)$ & $2.34(1.23-4.45)^{\star}$ & $<0.001^{*}$ \\
\hline Nutrient-rich foods (overall) & $64(50 \%)$ & $854(58 \%)$ & & \\
\hline \multicolumn{5}{|l|}{ Dinner } \\
\hline Energy dense food & $15(12 \%)$ & $103(7 \%)$ & 1.89 & $<0.001^{*}$ \\
\hline Nutrient-rich foods (overall) & $68(53 \%)$ & $883(60 \%)$ & $(1.04-3.43)^{*}$ & \\
\hline \multicolumn{5}{|l|}{ Snack/anything between meals } \\
\hline Energy dense food & $87(68 \%)$ & $662(45 \%)$ & $1.89(1.28-2.79)^{*}$ & $<0.001^{*}$ \\
\hline Nutrient-rich foods (overall) & $40(31 \%)$ & $574(39 \%)$ & & \\
\hline
\end{tabular}

Table 3: The risky socioeconomic factors associated with overweight

\begin{tabular}{|c|c|c|c|c|}
\hline Parameters & Overweight $(n=128) n(\%)$ & Normal $(n=1472) n(\%)$ & Test of sig. Odds ratio $(\mathrm{Cl})$ & $p$ value of Chi-square \\
\hline \multicolumn{5}{|l|}{ Child order } \\
\hline Child order $(\geq 3)(n=655)$ & $52(40.6 \%)$ & $613(41.6 \%)$ & \multirow[t]{2}{*}{$0.959(0.664-1.385)$} & \multirow[t]{2}{*}{$>0.05$} \\
\hline Child order (1-2) (n=935) & $76(59.4 \%)$ & $859(58.4 \%)$ & & \\
\hline \multicolumn{5}{|l|}{ Family size* } \\
\hline Large family (n=783) & $41(32.0 \%)$ & $742(50.4 \%)$ & \multirow[t]{2}{*}{$0.464^{*}(0.316-0.681)$} & \multirow[t]{2}{*}{$<0.001^{*}$} \\
\hline Small family ( $n=817$ ) & $87(68.0 \%)$ & $730(49.6 \%)$ & & \\
\hline \multicolumn{5}{|l|}{ Family income ${ }^{\star \star}$} \\
\hline Low-income family (n=843) & $50(39.1 \%)$ & 793 (53.9\%) & \multirow[t]{2}{*}{$0.549^{\star}(0.379-0.794)$} & \multirow[t]{2}{*}{$<0.001^{*}$} \\
\hline Middle-income family ( $\mathrm{n}=757$ ) & $78(60.9 \%)$ & $679(46.1 \%)$ & & \\
\hline \multicolumn{5}{|l|}{ 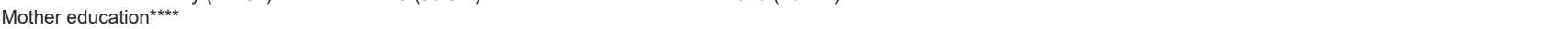 } \\
\hline Illiterate/read and write $(n=846)$ & $79(61.7 \%)$ & $675(45.9 \%)$ & \multirow[t]{2}{*}{$1.90^{*}(1.31-2.76)$} & \multirow[t]{2}{*}{$<0.001^{*}$} \\
\hline High education $(n=754)$ & $49(38.3 \%)$ & $797(54.1 \%)$ & & \\
\hline \multicolumn{5}{|l|}{ Father education ${ }^{* \star \star \star}$} \\
\hline Illiterate/read and write $(n=789)$ & $57(44.5 \%)$ & $732(49.7 \%)$ & \multirow[t]{2}{*}{$0.812(0.564-1.167)$} & \multirow[t]{2}{*}{$>0.05$} \\
\hline High education $(n=811)$ & $71(55.5 \%)$ & $740(50.3 \%)$ & & \\
\hline \multicolumn{5}{|l|}{ Father job } \\
\hline Don't work (n=29) & $1(0.8 \%)$ & $28(1.9 \%)$ & \multirow[t]{2}{*}{$0.406(0.054-3.009)$} & \multirow[t]{2}{*}{$>0.05$} \\
\hline Working $(n=1571)$ & $127(99.2 \%)$ & $1444(98.1 \%)$ & & \\
\hline \multicolumn{5}{|l|}{ Mother job } \\
\hline Don't work (n=1184) & $86(67.2 \%)$ & $1098(74.6 \%)$ & \multirow[t]{2}{*}{$0.697(0.474-1.027)$} & \multirow[t]{2}{*}{$>0.05$} \\
\hline Working $(n=416)$ & $42(32.8 \%)$ & $374(25.4 \%)$ & & \\
\hline
\end{tabular}

*Large family=Family size $\geq 6$, Small family=Family size $1-5,{ }^{*}$ Low income family: Father and mother are unemployed, day by day worker, farmer, or laborer, Middle income family: Father and mother are employee,

professional, employer, or dealer, ${ }^{* \star *}$ High education=High school and university ${ }^{*}=$ Sig. $<0.05$ 
inflammation status [18], [19]. Several studies confirmed the role played by obesity on the immune system leading to impaired immune responses to infection and this proves the close interaction between the metabolic control and immune tolerance [20].

Table 4: Predictors of overweight in primary school children according to logistic regression analysis

\begin{tabular}{lll}
\hline Parameters & $(\mathrm{B})$ & Sig. \\
\hline Taking breakfast (before or inside school) & -0.677 & 0.007 \\
Increase of family size & -0.590 & 0.014 \\
Taking breakfast before school & -0.875 & 0.001 \\
Taking dinner & -0.985 & 0.000 \\
Consumption of snack before sleep & +1.081 & 0.000 \\
Taking meals on time & -1.128 & 0.000 \\
Consumption of snacks between meals & +0.814 & 0.005 \\
Intake of sugar sweetened beverages & +1.600 & 0.000 \\
Intake of candies & +1.261 & 0.000 \\
Intake of chips & +1.362 & 0.012 \\
Increase of family income & +0.486 & 0.050 \\
Increase of maternal education & -0.519 & 0.056 \\
\hline Negative means: For continuous data with the increase, there is decrease in the risk of overweight and for
\end{tabular}

dichotomous data it means that with its absence the risk of overweight increase

Recently, COVID-19 invades the world and scientists are still trying to discover how it affects the body. As obesity may cause the body's immune response to go with unexpected speed leading to cytokines storm, it is now thought to be one of the biggest risk factors in developing severe coronavirus symptoms and even may play a significant role in coronavirus deaths [21].

In obese individuals, the dysfunctional adipose tissue is characterized by altered cytokine secretion patterns leading to severe changes in the serum level of inflammatory and anti-inflammatory cytokines, proteins, in the number, and behavior of immune cells and thus stimulate hyper-inflammation manifestation in severe COVID-19 and may decrease the immune system responsiveness to vaccines and microorganisms [18], [20], [22], [23], [24]. Altogether, obesity per see may be an independent risk factor for SARS-CoV-2 [3].

Preliminary data indicate that the new COVID-19 cases are increasing among younger and obese adults [25]. Deng et al., not only confirmed that obesity is a major and independent risk factor for COVID19 complications in young adults [26] but they also pointed out ectopic and visceral fat depots as potential markers of COVID-19 risk. A high prevalence of obesity in patients with severe COVID-19 requiring invasive mechanical ventilation was recently reported [27]. In developing countries, malnutrition among children is a major public health concern. Young children are the most vulnerable group due to their high nutritional requirements for growth and development. Overweight and obesity result from an imbalance between energy consumed (too much) and energy expended (too little) [28]. Higher prevalence of obesity is linked to poor diet quality, low physical activity, and excessive screen-time, (i.e., television, computers, e-devices such as smartphones, tablets) [29], [30]. In many countries, the school food environment promotes the consumption of unhealthy foods, overweight, and obesity [31].

The current cross-sectional observational study was conducted on primary school children aged 6-12 years. Of 1600 children, there were $8 \%$ overweight and this was higher than the global average of $6.2 \%$ [32]. Different studies had been conducted in different Egyptian governorates. Among Egypt, for the same comparable age group (6-12 years) much higher results for overweight percentage were reported in Alexandria, Sohag, and Menoufia governorates, (16.8\% and $16.5 \%$ and $23.7 \%$, respectively) although they worked on nearly the same age group. This so big difference could be attributed to different socioeconomic factors, eating habits, and lifestyle [33], [34]. In the present study, we found that children who carried higher risk to be overweight are those who missed their home breakfast; who did not take meals on time regularly; who did not take breakfast and snacks; did not take dinner; and who took snacks before sleep or between meals, $(\mathrm{OR}=4.031,3.31,2.82,2.53,2.2$, and 1.89 , respectively). Our results were matching to a great extent to those of Amin et al., in a study done in Saudi Arabia on primary school male children, where missing or infrequent intake of breakfast at home was a predictor of overweight among the studied children [35]. Similarly, many Egyptian studies on primary school children found that skipping breakfast was associated with obesity, while its regular consumption or having school meals as breakfast was associated with improved cognitive performance, nutritional adequacy, bone and cardiovascular health as well as healthy body weight [33], [36], [37]. The reason why skipping breakfast is associated with a higher weight is not well understood. According to UNICEF reports (2019), children who miss or skip breakfast have a higher BMI than their peers who do not; this is because they subsequently eat between meals more snacks and sweetened carbonated drinks that are high in calories but low in nutrients [6]. On the other hand, in a study carried in the USA, (2017) on school children they said that this may reflect some degree of reverse causality if overweight and obese students think skipping breakfast will help them lower caloric consumption [38]. In the present study, considering the weekly share of the stomach, one-third of overweight children and nearly half of normal weight children consumed nutrient-rich food in the form of dairy and beans/meat/eggs. It was also found that chips and SSB were consumed more than once per day among $96 \%$ and $90 \%$ of overweight children (respectively), while French fries were consumed less than once per day and candies nearly once per day in $95 \%$ and $78 \%$ among overweight children (respectively). Similarly Amin et al. mentioned that low consumption of nutrient food (fruits vegetables, milk, and dairy products), as well as frequent consumption of sweets and carbonated drinks, was all predictors of overweight among the studied children [35].

In Tanzania, it was found that random eating of different food categories such as pancakes, crisps, and juice for at least 5 days per week at school was predictor factors for both overweight and obesity. The majority of children missed breakfast and had irregular 
meals [39]. This was in accordance with our results where children who missed breakfast, who are not eating meals in time and who are eating more snacks carry more risk to be overweight than those who used to eat regularly.

In the current study, the majority of overweight children belonged to small families $(68.0 \%)$, middleincome families $(60.9 \%)$ and had illiterate or read and write mothers $(61.7 \%)$. Furthermore, our analysis shows that reduced risk of having overweight children came with large family size, low-income families, and with highly educated mothers $(\mathrm{OR}=0.46,0.55$, and 1.9, respectively). Other Egyptian studies, performed on a wider range of school age children (6-17 years), revealed different results compared to the present one. They concluded that the presence of higher percent of obesity was in association with large family size, low SES families in addition to higher percent of illiterate and not working mothers [29] or a lower percent of illiterate mothers [40]. The difference between our results and the previous studies could be attributed to the fact that they represent wider age range group, different geographical regions (urban and rural) with different sociodemographic characteristics and nutritional habits. Previous studies concluded that there is increasing numbers of families with both (or single parent) employed which may impact their abilities to support healthy lifestyles for their children [41], [42], [43] while another study have linked only maternal employment with childhood overweight [44]. In the present study, we found that overweight children belonged to middleincome families $(60.9 \%)$ where fathers and mothers were working $(99.2 \%$ and $32.8 \%$, respectively). The lower prevalence of overweight in our study compared to several previous studies done in Egypt, could be attributed to the fact that only one-third of the mothers were working while two-thirds were staying at home. Maternal working had a great impact on the nutritional state of their children due to limited time available for cooking more healthy diets [45], depending more on unhealthy takeout, restaurant meals and/or providing fast and easy prepared food [46], [47]. In addition to lack of maternal-child supervision and that may have adverse implications for their food intake choices and physical activity [45].

\section{Conclusion}

The prevalence of overweight among the studied group was much lower than that reported in other previous Egyptian studies. Nutritional behaviors and social factors had a profound effect for the development of overweight in children. Children with overweight should correct their unhealthy habits and take extra measures to avoid COVID-19 contamination by imposing prevention during the current pandemic. Achieved partnership for lasting change that encourages partnerships among parents and carers, governmental (Ministry of Health and Ministry of Education) that share the ambition to improve diets and health is highly required especially through the school feeding support program that proved to have high impact on children [36], [37]. The majority of the Egyptian researches indicated that it is critical to start feeding programs too early with more focus on the promotion of breast breastfeeding due to its marvelous effect on not only the physical growth and health but also on the child cognitive development [48], [49].

Management of the overweight problem necessitates not only the use of medication but to eat healthy to increase immunity. For low socioeconomic communities, this cannot be addressed without designing and implementing community-based programs that are dependent on the cooperation between physicians, parents, and teachers. Similar community-based initiative in Egypt assessed facilitators and barriers of behavioral change as well as addressed the psychosocial problems proved to have a very profound effect on to enhancing well-being. They are considered as compelling and promising solutions to parents and carers through raising their awareness, and improving birth outcome and leading to improve children immunity generally and against COVOID 19 in particular [50], [51], [52].

At the same time, for prevention and/or attenuating the pathological consequences of obesity, dietary intake of natural products together with antioxidant and anti-inflammatory is mandatory in addition to preventive measures and caloric restrictions.

\section{Strengths of the study}

Our study is characterized by being a facility based one on representing three different geographical areas with very large sample size (1600 children), with a high confidence level of $95 \%$ and low two-sided margin of error (0.05). The study targeted all determinants for overweight.

\section{Limitation of the study}

This study was limited to assess the weaknesses of the eating habits of overweight children as a weak point leading to increasing their vulnerability to catching COVID-19 infection without assessing the link to coronavirus infection and compare the incidence of its infection among overweight versus normal children. This might be considered as a weakness to our study, yet, because of the lockdown that all government agencies are doing to fight the adverse situation due to the COVID-19 pandemic efficiently, it was difficult to set and achieve this objective. 


\section{Declarations}

Ethics approval and consent to participate

\section{Ethical issues}

The study was approved by the Medical Research Ethics Committee of the National Research Centre with the ethical approval number of 19068. Permission to conduct the research was obtained from the Ministry of Education. Consent from the children's guardians was taken and the information obtained at the individual level was kept strictly confidential. The conduct of the study was complied with the International Ethical Guidelines for Biomedical Research Involving Human Subjects [53].

\section{Availability of data and materials}

The datasets used and/or analyzed during the current study are available from the corresponding author on reasonable request.

\section{Authors' Contributions}

The design of the study was done by AMM, EMS. All authors contributed to the implementation of the field visits and data collection. MMS, WS, and FSh assessed all the children to detect any abnormalities and conduct the anthropometric measures. $\mathrm{HH}$ did the statistical analyses. All authors shared for the interpretation. WS and MMS took the lead in writing the manuscript. AMM, FSh, and EMS reviewed the manuscript. All authors discussed the results and commented on the manuscript. All authors approved the manuscript.

\section{Acknowledgments}

The authors express their thanks and appreciation to the collaborative effort of Ministry of Education and the research team of the National Research Centre. Special thanks go to all parents for their willingness and cooperation during the implementation of the study along the three targeted governorates.

\section{References}

1. Ye ZW, Jin DY. Diagnosis, treatment, control and prevention of SARS-CoV-2 and coronavirus disease 2019: Back to the future.
Sheng Wu Gong Cheng Xue Bao. 2020;36(4):571-92.

PMid:32347053

2. The 2020 Global Nutrition Report in the Context of Covid-19. Available from: https://www.globalnutritionreport.org. [Last accessed on 2020 Apr 25].

3. Ryan DH, Ravussin E, Heymsfield S. COVID 19 and the patient with obesity-the editors speak out. Obesity (Silver Spring). 2020;28(5):847. https://doi.org/10.1002/oby.22808

PMid:32237212

4. Svedberg P. How many people are malnourished? Annu Rev Nutr. 2011;31:263-83. https://doi.org/10.1146/ annurev-nutr-081810-160805 PMid:21756133

5. Whitlock EP, Williams SB, Gold R, Smith PR, Shipman SA Screening and interventions for childhood overweight: A summary of evidence for the US preventive services task force. Pediatrics. 2010;116(1):e125-44. https://doi.org/10.1542/ peds.2005-0242

PMid:15995013

6. UNICEF, for Every Child, Nutrition, Appropriate Nutrition is Crucial for Optimal Growth and Development of Children; 2019. Available from: https://www.unicef.org/egypt/nutrition. [Last accessed on 2020 Apr 19].

7. Tuszczki E, Sobek G, BartosiewiczA, Baran J, Weres A, Dereń K, et al. Analysis of fruit and vegetable consumption by children in school canteens depending on selected sociodemographic factors. Medicina. 2019;55(7):397. https://doi.org/10.3390/ medicina55070397

PMid:31336674

8. Global Nutrition Report Shining a Light to Spur Action on Nutrition; 2018. Available from: http//:www.E:/date\%20project/SFP/ risk\%20factor\%20malnutrition/2018 Global_Nutrition_Report Executive_Summary.pdf. [Last accessed on 2020 Apr 01].

9. Hassanain Al, Ahmed FA, El-Sonbaty MM, Amgad $\mathrm{KH}$ Salem SM, William M. Relation of plasma ghrelin levels with leptin in obese children and adolescents. IJAR. 2012;4(1):119-24.

10. Diamond A. Interrelated and interdependent. Dev Sci. 2007;10(1):152-8.

PMid: 17181714

11. Datar A, Sturm R. Childhood overweight and elementary school outcomes. Int J Obes. 2006;30(9):1449-60. https://doi. org/10.1038/sj.ijo.0803311

PMid: 16534518

12. El-Masry SA, Gamal HA, Al-Tohamy M, Ayman N Abdelrahman $\mathrm{AH}$, Mohamed $\mathrm{M}$, et al. Infect-obesity in Egyptian adolescent women and its relations to carotid intima-media thickness. J Arab Soc Med Res. 2018;13(2):79. https://doi. org/10.4103/jasmr.jasmr_20_18

13. Hintze J. PASS 11. NCSS, LLC. Kaysville, Utah, USA. Available from: http://www.ncss.com. [Last accessed on 2019 Jul 07].

14. Newcombe RG. Two-sided confidence intervals for the single proportion: Comparison of seven methods. Stat Med. 1998;17(8):857-72. https://doi.org/10.1002/(sici)1097-0258 (19980430)17:8<857::aid-sim777>3.0.co;2-e PMid:9595616

15. Lohman TG, Roche AF, Martorell R. Anthropometric Standardization Reference Manual. Champaign, IL: Human Kinetics Publishers; 1988.

16. World Health Organization. Anthro-plus for personal computers. In: Manual Software for Assessing Growth of the World's Children and Adolescents. Geneva: World Health Organization; 2009. Available from: http://www.who.int/growthref/tools/en. [Last accessed on 2019 Jul 05].

17. SPSS IBM Corp. Released. IBM SPSS Statistics for Windows, Version 24.0. Armonk, NY: SPSS IBM Corp; 2016. 
18. Dobner J, Kaser S. Body mass index and the risk of infection-from underweight to obesity. Clin Microbiol Infect. 2018;24(1):24e-8. https://doi.org/10.1016/j.cmi.2017.02.013

\section{PMid:28232162}

19. Magrone T, Jirillo E. Childhood obesity: Immune response and nutritional approaches. Nutr Immunol. 2015;6:76. https://doi. org/10.3389/fimmu.2015.00076

PMid:25759691

20. Carbone F, La Rocca C, De Candia P, Procaccini C, Colamatteo A Micillo $\mathrm{T}$, et al. Metabolic control of immune tolerance in health and autoimmunity. Semin Immunol. 2016;28(5):491e-504. https://doi.org/10.1016/j.smim.2016.09.006

PMid:27720234

21. Achofield C. Why Being Overweight Could Put You at a More Risk of Severe Coronavirus Symptoms; 2020. https://www. rugbyadvertiser.co.uk. [Last accessed on 2020 May 01].

22. Umano GR, Pistone C, Tondina E, Moiraghi A, Lauretta D, Del Giudice EM, et al. Pediatric obesity and the immune system. Front Pediatr. 2019;7:487.

PMid:31824900

23. Kelishadi R, Roufarshbaf M, Soheili S, Payghambarzadeh F, Masjedi M. Association of childhood obesity and the immune system: A systematic review of reviews. Child Obes. 2017;13(4):332-46. https://doi.org/10.1089/chi.2016.0176 PMid:28604080

24. Luzi L, Radaelli MG. Influenza and obesity: Its odd relationship and the lessons for the COVID-19 pandemic. Acta Diabetol 2020;57(6):759-64. https://doi.org/10.1007/ s00592-020-01522-8

PMid:32249357

25. lacobellis G, Malavazos AE, Ferreira T. COVID-19 rise in younger adults with obesity: Visceral adiposity can predict the risk. Obesity (Silver Spring). 2020. https://doi.org/10.1002/ oby.22951

26. Deng M, Qi Y, Deng L, Wang H, Xu Y, Li Z, et al. Obesity as a Potential Predictor of Disease Severity in Young COVID19 Patients: A Retrospective Study. Obesity (Silver Spring). Obesity as a Potential Predictor of Disease Severity in Young COVID-19 Patients: A Retrospective Study; 2020.

27. Simonnet A, Chetboun M, Poissy J, Raverdy V, Noulette J, Duhamel A, et al. High prevalence of obesity in severe acute respiratory syndrome coronavirus-2 (SARS-CoV-2) requiring invasive mechanical ventilation. Obesity. 2020;28(7):1195-9. https://doi.org/10.1002/oby.22831

PMid:32271993

28. WHO. Malnutrition; 2018. Available from: https://www.who.int/ news-room/fact-sheets/detail/malnutrition. [Last accessed on 2019 May 01].

29. Wahed WY, Hassan SK, Eldessouki R. Malnutrition and its associated factors among rural school children in Fayoum governorate, Egypt. J Environ Public Health. 2017;2017:4783791. https://doi.org/10.1155/2017/4783791

30. Hadhood SE, Ali RA, Mohamed MM, Mohammed ES. Prevalence and correlates of overweight and obesity among school children in Sohag, Egypt. Open J Gastroenterol. 2017;7(2):75-88. https:// doi.org/10.4236/ojgas.2017.72009

31. Al-Ghannami S, Al-Shammakhi S, Al Jawaldeh A, Al-Mamari F, Al Gammaria I, Al-Aamry J, et al. Rapid assessment of marketing of unhealthy foods to children in mass media, schools and retail stores in Oman. East Mediterr Health J. 2019;25(11):820-7. https://doi.org/10.26719/emhj.19.066 PMid:31782519

32. Global Nutrition Report, Egypt. Country Overview; 2019. Available from: https://www.globalnutritionreport.org/resources/ nutrition-growth-commitment-tracking. [Last accessed on 2020
Jan 31].

33. El-Shafie A, Hogran H, Dohein A. Prevalence of obesity in primary school children living in Alexandria governorate. Menoufia Med J. 2014;27:529-32. https://doi.org/10.4103/1110-2098.145502

34. Taha AA, Marawan HM. Socio-behavioral determinants of overweight and obesity in Egyptian primary school children. J Child Adolesc Behav. 2015;3:236. https://doi. org/10.4172/2375-4494.1000236

35. Amin TT, Al-Sultan Al, Ali A. Overweight and obesity and their association with dietary habits and sociodemographic characteristics among male primary school children in Al-Hassa, Kingdom of Saudi Arabia. Indian J Community Med. 2008;33(3):172-81. https://doi.org/10.4103/0970-0218.42058 PMid:19876479

36. Metwally AM, El-Sonbaty MM, El Etreby LA, Salah El-Din EM, Hamid NA, Hussien HA, et al. Impact of national Egyptian school feeding program on growth, development and school achievement of school children. World J Pediatr. 2020; 16(4):393-400. https://doi.org/10.1007/s12519-020-00342-8 PMid:32056148

37. Salah EM, Khalifa AG, Metwally AM., Hamid NA, Hussien HA, Moneer ZM. The impact of school snacks on cognitive function of primary school children in Egypt. J Appl Sci Res. 2012;8(12):5639-50.

38. Wang S, Schwartz MB, Shebl FM, Read M, Henderson KE, Ickovics JR. School breakfast and body mass index: A longitudinal observational study of middle school students. Pediatr Obes. 2017;12(3):213-20. https://doi.org/10.1111/ ijpo.12127 PMid:26989876

39. Chomba H, Haikael M, Judith K. Prevalence and predictors of obesity among 7-to 17-year-old schoolchildren in Urban Arusha, Tanzania. J Nutr Metab. 2019;2019:3106597. https:// doi.org/10.1155/2019/3106597

PMid:31772772

40. El Serougy S, Salama S, Salama I, Shaaban F, Sami S. Effects of obesity and some sociodemographic determinants on health-related quality of life in school-aged children in greater Cairo. Med Res J. 2012;11(1):12-9. https://doi.org/10.1097/01. mjx.0000414712.54546.57

41. Organization for Economic Co-operation and Development Doing Better for Families. Paris: Organization for Economic Co-operation and Development; 2011.

42. Organization for Economic Co-operation and Development. Babies and Bosses: Reconciling Work and Family Life: A Synthesis of Findings from OECD Countries. Paris: Organization for Economic Co-operation and Development; 2007.

43. Cawley J, Liu F. Maternal employment and childhood obesity: A search for mechanisms in time use data. Econ Hum Biol. 2012;10(4):352-64. https://doi.org/10.3386/w13600 PMid:22790446

44. Hope S, Pearce A, Whitehead M, Law C. Parental employment during early childhood and overweight at 7-years: Findings from the UK millennium cohort study. BMC Obes. 2015;2:33. https:// doi.org/10.1186/s40608-015-0065-1 PMID:26388995

45. Monsivais $P$, Aggarwal A, Drewnowski A. Time spent on home food preparation and indicators of healthy eating. Am J Prev Med. 2014;47(6):796-802. https://doi.org/10.1016/j. amepre.2014.07.033 PMid:25245799

46. Devine CM, Farrell TJ, Blake CE, Jastran M, Wethington E, Bisogni CA. Work conditions and the food choice coping strategies of employed parents. J Nutr Educ Behav. 2009;41(5):365-70. https://doi.org/10.1016/j.jneb.2009.01.007 
PMid:19717121

47. Devine CM, Jastran M, Jabs J, Wethington E, Farell TJ, Bisogni CA. A lot of sacrifices: Work-family spillover and the food choice coping strategies of low-wage employed parents. Soc Sci Med. 2006;63(10):2591-603. https://doi.org/10.1016/j. socscimed.2007.04.036

PMid:16889881

48. Salah El-Din EM, Elabd MA, Nassar MS, Metwally AM, Abdellatif GA, Rabah TM, et al. The interaction of social, physical and nutritive factors in triggering early developmental language delay in a sample of Egyptian children. Open Access Maced J Med Sci. 2019;7(17):2767-74. https://doi.org/10.3889/ oamjms.2019.642

PMid:31844434

49. Metwally AM, Salah El-Din EM, Shehata MA, Shaalan A, E Etreby LA, Kandeel WA, et al. Early life predictors of socioemotional development in a sample of Egyptian infants. PLoS One. 2016;11(7):e0158086. https://doi.org/10.1371/journal. pone.0158086

PMid:27379907

50. Metwally AM, Soliman M, Abdelmohsen AM, Kandeel WA, Saber M, Elmosalami DM, et al. Effect of counteracting lifestyle barriers through health education in Egyptian Type 2 diabetic patients. Open Access Maced J Med Sci. 2019;7(17):2886-94. https://doi.org/10.3889/oamjms.2019.624

PMid:31844454

51. Metwally AM, Ibrahim NA, Saad A, El Ela MA. Improving rural women role in health and environmental issues. Int J Environ Health Res. 2006;16(2):44-133. https://doi. org/10.1080/09603120500539208

PMid:16546806

52. Metwally AM, Abdel-Latif GA, Mohsen A, El Etreby L, Elmosalami DM, Saleh RM, El-Sonbaty MM, et al. Strengths of community and health facilities based interventions in improving women and adolescents' care seeking behaviors as approaches for reducing maternal mortality and improving birth outcome among low income communities of Egypt. BMC Health Serv Res. 2020;20(1):592. https://doi.org/10.1186/s12913-020-05412-1 PMid:32600377

53. Council for International Organizations of Medical Science. A Nongovernmental Organization in Official Relations with WHO, International Ethical Guidelines for Biomedical Research Involving Human Subjects. Geneva: Council for International Organizations of Medical Science; 2016. 